\title{
A Final das OLImpíadas de Química JúnIoR 2011 na UTAD
}

Neste Ano Internacional da Química, a final das Olimpíadas de Química Júnior teve lugar no bonito campus da Universidade de Trás-os-Montes e Alto Douro, em Vila Real. As provas decorreram no passado dia 7 de Maio, mas na realidade a confraternização começou no dia anterior, com uma recepção às equipas participantes no hotel onde a SPQ possibilitou que ficassem todas alojadas.

No dia das provas estava planeada uma caminhada desde o hotel até à Universidade, a fim de se começar o dia com um espírito desportivo e desfrutar, simultaneamente, de um percurso singular ao longo das fragas do rio Corgo até ao Jardim Botânico da UTAD, mas a chuva obrigou a uma mudança de planos, mesmo à última da hora. Ainda assim, a boa disposição manteve-se, o sol reapareceu e às $10.15 \mathrm{~h}$ teve início a Sessão de Abertura com a presença do Presidente da nossa Escola, Prof. Fontainhas Fernandes, e da Directora do Departamento de Química, Profa . Verónica Bermudez.

Depois de uma breve explicação sobre o funcionamento das provas, as 19 equipas, distribuídas por 4 grupos, partiram para 2 horas de desafios experimentais, teóricos e lúdicos que decorreram simultaneamente em 4 salas. De salientar "a prova do kit ", muito apreciada por todos; nesta prova pedia-se aos alunos para desempenharem várias tarefas experimentais, sendo-Ihes apenas fornecido um "kit de química" que incluía o material e reagentes necessários ao desempenho das tarefas.

Enquanto decorriam as provas, os professores acompanhantes tiveram a oportunidade de realizar a "difícil" prova de degustação de várias iguarias preparadas no workshop sobre Gastronomia Molecular, intitulado "Os Cinco Sentidos da Química” e organizado pelos nossos colegas Ana Barros e Fernando Nunes.

Depois das actividades da manhã, seguiu-se o almoço, oferecido pela reitoria da UTAD, e o reencontro dos alunos com os respectivos professores, aqui confrontados com algumas dúvidas que assaltaram os seus pupilos durante as provas. De um modo geral os alunos acharam que as provas tinham sido um pouco difíceis, mas aliciantes.

A tarde começou com a passagem de um filme sobre as actividades desenvolvidas pelo Departamento de Química da UTAD, a que se seguiu o seminário "O gelado Químico", proferido pelo nosso colega Fernando Braga, que contou com a preciosa colaboração de alguns "destemidos" alunos. O seminário terminou com todos a provarem o saboroso gelado acabadinho de ser feito.

Por fim, chegou o momento mais desejado: o anúncio dos vencedores! $A$ equipa vencedora, que irá no próximo ano à Lituânia representar Portugal nas Olimpíadas Europeias de Ciência, foi a equipa "Salesianos", da Escola
Técnica e Liceal Salesiana de Sto. António, vinda do Estoril, constituída pelos alunos Afonso Tinoco, Bruno Oliveira e Diogo Dias e orientada pela Profa. Rita Silva. Para eles aqui ficam os nossos parabéns e votos de muito sucesso nas provas europeias. Os $2^{\circ}$ e $3^{\circ}$ lugares foram conquistados, respectivamente, pela equipa "Os Isótopos", constituída pelos alunos Jorge Ribeiro, Marcelo Oliveira e Joana Queirós, da Escola Básica dos $2^{\circ} \mathrm{e}$ $3^{\circ}$ ciclos D. Manuel de Faria e Sousa, Felgueiras, orientada pelo Prof. Luís Miguel Martins, e pela equipa "Triatómica", constituída pelos alunos Ana Ferreira, Ana Martinho e Nuno Silva, da Escola Básica dos $2^{\circ}$ e $3^{\circ}$ ciclos de Caldas das Taipas, orientada pela Profa $^{a}$. Isabel Monteiro.

Depois do encerramento tínhamos à nossa espera um lanche, oferecido pela nossa Escola e animado pela Tuna Académica da UTAD. Ainda antes da despedida houve tempo para cantar os parabéns à SPQ pelos seus 100 anos e apagar as velas do bolo de aniversário, tarefa atribuída à equipa vencedora.

Para terminar, não podemos deixar de agradecer a todos aqueles que connosco colaboraram para que este dia tenha sido uma verdadeira "Festa da Química" que decerto ficará na memória de todos como um dia para "mais tarde recordar".

Maria Cristina Oliveira, Maria João Carvalho e Paulo Fernando Santos (quimica@utad.pt)

Departamento de Química da UTAD

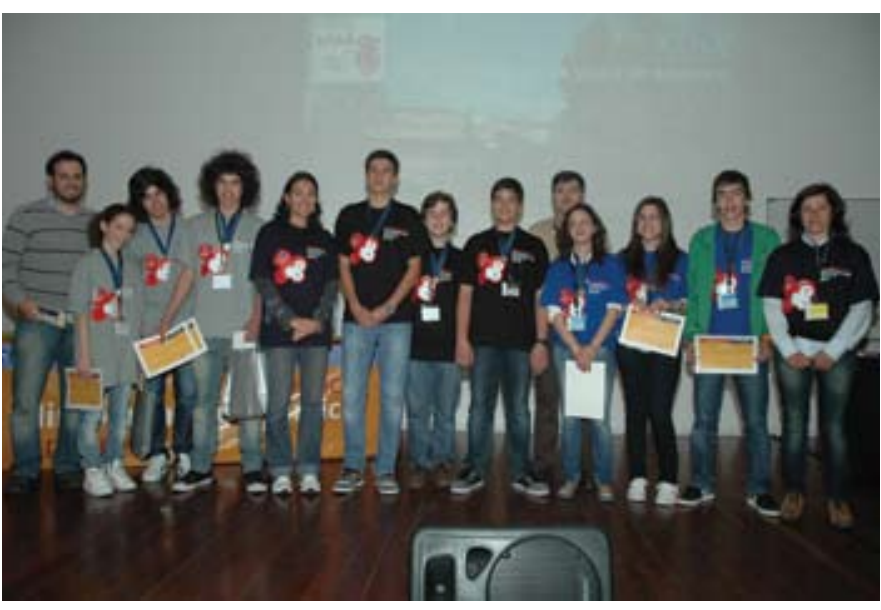

Equipas Vencedoras das Olimpíadas de Química Júnior 2011

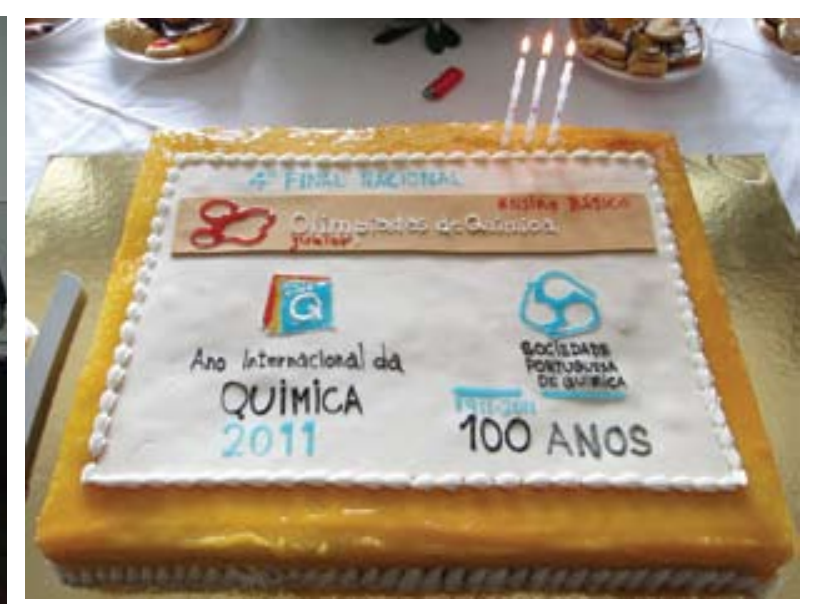

Bolo de Aniversário dos 100 Anos da SPQ 